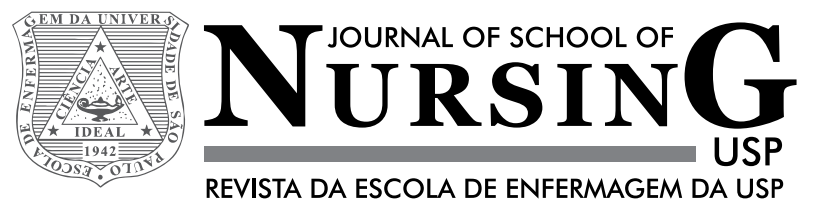

ORIGINAL ARTICLE

DOI: 10.1590/S0080-623420150000400002

\title{
Factors associated with the quality of prenatal care: an approach to premature birth
}

\author{
Fatores associados à qualidade do pré-natal: uma abordagem ao nascimento prematuro \\ Factores asociados con la calidad del prenatal: un abordaje al nacimiento prematuro
}

\author{
Emiliana Cristina Melo ${ }^{1}$, Rosana Rosseto de Oliveira², Thais Aidar de Freitas Mathias ${ }^{2}$
}

\footnotetext{
${ }^{1}$ Universidade Estadual do Norte do Paraná, Campus Luiz Meneghel, Bandeirantes, PR, Brazil.

${ }^{2}$ Universidade Estadual de Maringá, Departamento de Enfermagem, Maringá, PR, Brazil.
}

\section{ABSTRACT}

Objective: To assess the quality of prenatal care in mothers with premature and term births and identify maternal and gestational factors associated with inadequate prenatal care. Method: Cross-sectional study collecting data with the pregnant card, hospital records and interviews with mothers living in Maringa-PR. Data were collected from 576 mothers and their born alive infants who were attended in the public service from October 2013 to February 2014, using three different evaluation criteria. The association of prenatal care quality with prematurity was performed by univariate analysis and occurred only at Kessner criteria $(\mathrm{CI}=1.79 ; 8.02)$. Results: The indicators that contributed most to the inadequacy of prenatal care were tests of hemoglobin, urine, and fetal presentation. After logistic regression analysis, maternal and gestational variables associated to inadequate prenatal care were combined prenatal (CI=2.93;11.09), nonwhite skin color $(\mathrm{CI}=1.11 ; 2.51)$; unplanned pregnancy $(\mathrm{CI}=1.34 ; 3.17)$ and multiparity $(\mathrm{CI}=1.17 ; 4.03)$. Conclusion: Prenatal care must follow the minimum recommended protocols, more attention is required to black and brown women, multiparous and with unplanned pregnancies to prevent preterm birth and maternal and child morbimortality.

\section{DESCRIPTORS}

Prenatal Care; Premature Birth; Maternal-Child Nursing; Evaluation Studies. 


\section{INTRODUCTION}

Recent studies highlight proper prenatal care as a determining factor in preventing maternal and child morbimortality ${ }^{(1-3)}$, as it contributes to more favorable outcomes from the accomplishment of the basic procedures such as conducting clinical and laboratory tests and monitoring the pregnancy through regular visits that enable detection and timely treatment of risk factors that bring complications for the mother and child health.

Despite the important role that prenatal care has on maternal and child health, some data show impaired quality of care, as the incidence of congenital syphilis and gestational hypertension, which if not properly diagnosed and treated can trigger undesirable consequences for the mother and child. These and other gestational events, with varying degrees of sequelae, can be decisive for the maternal and neonatal death, such as congenital malformations, infections, pre-eclampsia and eclampsia, poor fetal weight gain and premature birth ${ }^{(4)}$, internationally considered one of the major public health problems of our time ${ }^{(5-7)}$.

This perinatal problem has shown progressive increase in most countries, being appointed as the first cause of death in children under 5 years of age $\mathrm{e}^{(6)}$. The highest rates observed in 2005 were in the United States of America (12.5\%) and in African countries (11.9\%). Smaller proportions $(6.2 \%)$ were found in European countries ${ }^{(5)}$. In Brazil, the proportion of premature births was $5 \%$ in 2005, which rose to $11.9 \%$ in 2012, and in Parana the increased went from $6.2 \%$ to $7.5 \%$, with significant regional differences within the state ${ }^{(8)}$.

In the city of Maringa, the proportion of premature birth increased from $7.1 \%$ to $13.2 \%$ in this period ${ }^{(9)}$, higher prevalence and growth to that presented by all the cities in Parana and Brazil.

The contradictions between the results from different regions suggest that premature birth involves several factors that can vary between different regions, including the incidence of inductions of deliveries without clinical indication of cesarean and the use of assisted reproductive technologies ${ }^{(10)}$. In addition, variations in socioeconomic, cultural and health characteristics between populations require health services to have sufficient quality to detect them and, if possible, resolve them during the prenatal care ${ }^{(4)}$.

With this understanding, this study aimed to evaluate the quality of prenatal care for mothers with premature and term births and identify maternal and gestational factors associated with inadequate prenatal care in SUS (Unified Health System) in the city of Maringa-PR, Brazil. These associations can contribute to managers, nurses and other members of health teams in planning actions based on the characteristics of population and the limitations of prenatal care, in view of the decrease of prematurity.

\section{METHOD}

Cross-sectional study with data collection made through the pregnant card, hospital records and interviews with mothers living in Maringa-PR, who underwent prenatal care and delivery in the public health service, whose children were born alive. Maringa, in the northwest of Parana, has a population estimated at 391,698 inhabitants and HDI of $0.84^{(11)}$. The primary health care network consists of 27 basic units and 64 teams of the Family Health Strategy (FHS) with estimated coverage of $66 \%$ of FHS. It has nine general hospitals, two of which perform the delivery by the Unified Health System (SUS) ${ }^{(12)}$.

The sample of 576 mothers was calculated considering the prevalence of $13 \%$ of premature births in the city, estimated for the year 2013 with data from the Live Births Information System - SINASC, 95\% confidence level, sampling error of $2.5 \%$, and additional $10 \%$ for possible losses. Data were collected on daily visits in the two hospitals attending SUS from October 2013 to February 2014, using an adapted instrument from previous study ${ }^{(13)}$.

We used an electronic questionnaire using Google Docs, a technological tool that allows agility in the collection and tabulation of data, which are exported to a spreadsheet previously prepared by the researchers. To investigate the adequacy and compliance of the information, some records were double checked and a telephone call was made to the mother.

To assess the quality of prenatal care, the following data were collected from pregnant women cards: number of prenatal consultations; gestational age (GA) at the first visit; number of times that the GA was verified; number of times that the following tests were conducted: hemoglobin $(\mathrm{Hb})$, serology for syphilis (VDRL) and urine (ECU); number of times that uterine height (UH) was verified, fetal presentation (FP), fetal heart rate (FHR), blood pressure (BP) and weight. Analysis of the quality of prenatal care was performed using three criteria adapted from the Brazilian Ministry of $\mathrm{Health}^{(3)}$ as described below.

First criterion: Kessner index ${ }^{(14)}$, which classifies prenatal care in: adequate when the initiation of care occurs before 16 weeks of pregnancy and the mother perform at least six visits; inadequate when the initiation of care occurs after 28 weeks gestation; intermediate in other situations.

Second criterion: proposed by Silveira, Santos and Costa ${ }^{(15)}$, which adds to the Kessner index the number of times that laboratory tests (Hb, VDRL and ECU) were performed, being defined: adequate when care began before 16 weeks of gestation, the mother performed at least six visits and twice each of the three tests; inadequate when the care started after 28 weeks of gestation, or the pregnant woman performed less than three consultations or no test; intermediate in other situations.

Third criterion: Also proposed by Silveira, Santos and Costa ${ }^{(15)}$, which adds to the previous criteria the number of times the uterine height, fetal presentation, FHR, GA, BP and weight were checked, considering: adequate when the care began before 16 weeks of gestation, six or more visits are performed, at least twice each of the three laboratory tests, checking at least five times the uterine height, GA, BP and weight, four times FHR and three times fetal presentation; inadequate when the care initiated after 28 weeks, or the pregnant woman performed less than three consultations or 
no laboratory tests, or was checked two or fewer records of uterine height, GA, BP, FHR and weight, and no fetal presentation registration; intermediate in other situations.

To assess the quality of prenatal care when the outcome is premature birth, the Kessner index ${ }^{(14)}$ and the criteria proposed by Silveira, Santos and Costa ${ }^{(15)}$ were adapted to the recommended minimum for each gestational age as: GA at the first visit, the number of visits, each of the three tests (hemoglobin, syphilis and urine) and checks the uterine height, BP, FHR, weight, and fetal presentation, considering that the first visit should not exceed 120 days and the interval between them should be a maximum of four weeks. The first set of minimum tests should be performed before the $20^{\text {th }}$ week of pregnancy and the second set before the $30^{\text {th }}$. The uterine height, fetal presentation, FHR, GA, BP and weight, when ignored, must be recorded: Not done in the prenatal $\operatorname{card}^{(4)}$.

Prematurity was estimated by the GA at birth (less than 37 weeks premature and 37 weeks or more, term). For this, it was considered firstly the GA estimated by ultrasonography (USG) conducted until the $20^{\text {th }}$ week of pregnancy, described as the most accurate method ${ }^{(16)}$. In the absence of USG or if this was performed after the $20^{\text {th }}$ week, the GA was determined by last menstrual period (LMP), as proposed by SINASC ${ }^{(17)}$. If the pregnant woman had no knowledge or certainty of LMP, we used the clinical estimate of the obstetrician, biologically plausible ${ }^{(18)}$. So for $78 \%$ of cases the GA was established by USG, in $15.8 \%$ by LMP and $6.2 \%$ for the registration of GA by the obstetrician.

For the association of the quality of prenatal care, the following maternal characteristics were considered as variables: socioeconomic and individual of the pregnant woman: age ( $<20$, from 20 to 34 or $\geq 35$ years); education $(<8$ or $\geq 8$ years of study); ethnicity/color (white or non-white); work outside the home (yes or no); per capita family income $(<0.5,0.5$ to 1 or $>1$ minimum wage); marital status (with partner or without partner); planned pregnancy (yes or no); prenatal funding (only SUS or mixed); reproductive history and pre-existing conditions (parity: primiparous or multiparous); obstetrical history risk (previous premature child; previous child with low birth weight, miscarriage or fetal death (yes or no)); use of chemical substances (alcohol, tobacco, other drugs (yes or no)); birth interval ( $<24$, from 24 to 59 or $\geq 60$ months); characteristics and complications of pregnancy (multiple pregnancy (yes or no)); hypertension (yes or no); diabetes (yes or no); urinary tract infection (yes or no); STD/HIV (yes or no); anemia (yes or no).

The association between the quality of prenatal and premature birth was calculated using the association measure Odds Ratio (OR). For the association of the quality of prenatal care and the mother's characteristics, we used the logistic regression model (stepwise forward, using the SPSS software, version 20.1), in order to obtain odds ratio (OR) and adjusted odds ratio (AOR) with 95\% confidence level (CI).

We only present the results of the analysis of quality according to the first criterion (Kessner index) since the early initiation of prenatal care and the proper number of consultations can influence the achievement of clinical and laboratory tests ${ }^{(14)}$. In addition, premature birth was not associated with the quality of prenatal care for the first criterion. All variables with $\mathrm{P}$ value $<0.20$ in the univariate analysis were included in multivariate analysis, and the final model remained those with $\mathrm{P}$ value $<0.05$. The variables in the univariate association analysis had $\mathrm{P}$ value $>0.20$ were not shown in the results. The categories chosen as reference were those at lower risk for premature birth and for improper prenatal care.

All pregnant women signed the consent form (CF). The project was approved by the Research Ethics Committee of the Universidade Estadual de Maringa-PR (N 412.422/2013), fulfilling all ethical principles of the $\mathrm{Na}-$ tional Health Council Resolution 466/2012.

\section{RESULTS}

Among the 576 pregnant women living in Maringa who performed prenatal care and delivery by SUS, the prevalence of preterm births was $17 \%$. The evaluation of the quality of prenatal care (Table 1 ) revealed differences in the proportions observed among the three proposed criteria for the entire sample, with a higher proportion of improper prenatal care as the assessment became more rigid, from $5.7 \%$ observed in the analysis for the first criterion, combining GA at the first visit with the minimum number of visits, to $57.8 \%$ in the second criterion, which adds the minimum number of laboratory tests and $90.8 \%$ in the third criterion, which adds the number of times the minimum clinical tests were performed.

Table 1 - Prenatal care quality and association with preterm birth - Maringa, PR, Brazil, 2014.

\begin{tabular}{|c|c|c|c|c|c|c|}
\hline $\begin{array}{l}\text { Quality of } \\
\text { prenatal care }\end{array}$ & $\begin{array}{c}\text { Total } \\
\mathbf{n}=576 \\
(\mathbf{1 0 0} \%)\end{array}$ & $\begin{array}{c}\text { Term } \\
n=478 \\
(83 \%)\end{array}$ & $\begin{array}{c}\text { Premature } \\
\mathbf{n = 9 8} \\
(\mathbf{1 7 \% )}\end{array}$ & OR & $95 \% \mathrm{Cl}$ & $P$ value \\
\hline \multicolumn{7}{|l|}{ 1st criterion* } \\
\hline Adequate & 424(73.6) & $362(75.7)$ & $62(63.2)$ & & & \\
\hline Inadequate & $33(5.7)$ & $20(4.2)$ & 13 (13.6) & 3.79 & $(1.79 ; 8.02)$ & $<0.001$ \\
\hline Intermediate & $119(20.7)$ & $96(20.1)$ & $23(23.5)$ & 1.39 & $(0.82 ; 2.37)$ & 0.213 \\
\hline \multicolumn{7}{|l|}{ 2nd criterion** } \\
\hline Adequate & $71(12.3)$ & $61(12.8)$ & $10(10.2)$ & & & \\
\hline Inadequate & $333(57.8)$ & $273(57.1)$ & $60(61.2)$ & 1.34 & $(0.64 ; 2.76)$ & 0.428 \\
\hline Intermediate & 172(29.9) & $144(30.1)$ & $28(28.6)$ & 1.18 & $(0.54 ; 2.59)$ & 0.669 \\
\hline
\end{tabular}


...continuation

\begin{tabular}{|c|c|c|c|c|c|c|}
\hline $\begin{array}{l}\text { Quality of } \\
\text { prenatal care }\end{array}$ & $\begin{array}{c}\text { Total } \\
\mathbf{n}=\mathbf{5 7 6} \\
(\mathbf{1 0 0} \%)\end{array}$ & $\begin{array}{c}\text { Term } \\
n=478 \\
(83 \%)\end{array}$ & $\begin{array}{c}\text { Premature } \\
\mathbf{n}=\mathbf{9 8} \\
(\mathbf{1 7} \%)\end{array}$ & OR & $95 \% \mathrm{Cl}$ & $P$ value \\
\hline \multicolumn{7}{|c|}{ 3rd criterion $* * *$} \\
\hline Adequate & $9(1.6)$ & $8(1.7)$ & $1(1.0)$ & & & \\
\hline Inadequate & $523(90.8)$ & 433 (90.6) & $90(91.8)$ & 1.66 & $(0.20 ; 13.46)$ & 0.634 \\
\hline Intermediate & $44(7.6)$ & $37(7.7)$ & $7(7.2)$ & 1.51 & $(0.16 ; 14.08)$ & 0.716 \\
\hline
\end{tabular}

* Early initiation of prenatal care and number of consultations (Kessner index); ** First criterion plus minimum laboratory tests (proposed by Silveira, Santos and Costa, 2001) $)^{(15)}$.*** Second criterion plus obstetric minimum clinical procedures (proposed by Silveira, Santos and Costa, 2001) ${ }^{(15)}$.

The quality of prenatal care for mothers of premature infants was always poorer than to those mothers with term infant (Table 1). It is noteworthy that when the first criterion is applied, $75.7 \%$ of mothers with term children had adequate prenatal care, while for those with premature children, the adequate prenatal care was $63.2 \%$. There was an association between the quality of prenatal care and preterm birth only when the first criterion was used $(\mathrm{OR}=3.79, \mathrm{CI}=1.79 ; 8.02)$.

Among the indicators analyzed in each evaluation criteria (Table 2), the highest proportion of adequacy was observed for those who were part of the third criterion, especially for checking blood pressure $(89.6 \%$ adequate) FHR ( $87.7 \%$ adequate) and weight ( $87.0 \%$ adequate). The indicators analyzed for the first criterion, $\mathrm{GA}<16$ at the first visit and number of visits also had higher adequate proportion $80 \%$ (81.2\% and $85.4 \%$, respectively). We highlight the second criterion indicators, with high proportions of inadequacy (50.0\% of syphilis test, $58.5 \%$ urine tests and 78.5\% hemoglobin test).

Except for hemoglobin tests, not performed in 79.5\% of mothers with term children and $73.5 \%$ of premature, the test for syphilis diagnosis (50.0\% for both groups), and auscultation the FHR (13.3\% for the group with term and $12.2 \%$ for the group with premature), all other indicators showed higher proportion of inadequacy for mothers with premature children. We highlight the verification of uterine height, with greater proportional difference between the groups ( $41.8 \%$ for the group with premature and $25.3 \%$ for the group with term), followed by GA $<16$ weeks in the first visit $28.6 \%$ for the group with premature and $16.7 \%$ for the group with term) and number of visits $(22.4 \%$ for the group with premature and $13.0 \%$ for the group with term) (Table 2).

Table 2 - Quality of indicators for each criterion and association with preterm birth - Maringa, PR, Brazil, 2014.

\begin{tabular}{|c|c|c|c|c|c|c|c|c|}
\hline Criteria & Indicator & *Quality & Total $n=576(100 \%)$ & Term n=478 $(83 \%)$ & Premature $n=98(17 \%)$ & OR & $95 \% \mathrm{Cl}$ & $P$ value \\
\hline \multirow{4}{*}{$\begin{array}{l}* * 1^{\text {st }} \\
\text { criterion }\end{array}$} & \multirow{2}{*}{$\begin{array}{l}G A<16 \text { In the } \\
\text { first visit }\end{array}$} & Adequate & $468(81.2)$ & $398(83.3)$ & $70(71.4)$ & & & \\
\hline & & Inadequate & $108(18.8)$ & $80(16.7)$ & $28(28.6)$ & 1.99 & $(1.20 ; 3.28)$ & 0.007 \\
\hline & \multirow{2}{*}{$\begin{array}{c}\text { Number of } \\
\text { consultations }\end{array}$} & Adequate & $492(85.4)$ & $416(87.0)$ & $76(77.6)$ & & & \\
\hline & & Inadequate & $84(14.6)$ & $62(13.0)$ & $22(22.4)$ & 1.94 & $(1.12 ; 3.34)$ & 0.017 \\
\hline \multirow{6}{*}{$\begin{array}{l}* * * 2^{\text {nd }} \\
\text { criterion }\end{array}$} & \multirow{2}{*}{$\begin{array}{c}\text { Hemoglobin } \\
\text { test }\end{array}$} & Adequate & $124(21.5)$ & $98(20.5)$ & $26(26.5)$ & & & \\
\hline & & Inadequate & $452(78.5)$ & $380(79.5)$ & $72(73.5)$ & 0.71 & $(0.43 ; 1.17)$ & 0.187 \\
\hline & \multirow{2}{*}{ Syphilis test } & Adequate & $288(50.0)$ & $239(50.0)$ & $49(50)$ & & & \\
\hline & & Inadequate & $288(50.0)$ & $239(50.0)$ & $49(50.0)$ & 1.00 & $(0.64 ; 1.54)$ & 1.000 \\
\hline & \multirow{2}{*}{ Urine test } & Adequate & $239(41.5)$ & $202(42.3)$ & $37(37.8)$ & & & \\
\hline & & Inadequate & $337(58.5)$ & $276(57.7)$ & $61(62.2)$ & 1.20 & $(0.77 ; 1.88)$ & 0.410 \\
\hline \multirow{12}{*}{$\begin{array}{l}* * * * 3^{\text {rd }} \\
\text { criterion }\end{array}$} & \multirow{2}{*}{ Uterine height } & Adequate & $414(71.9$ & $357(74.7)$ & $57(58.2)$ & & & \\
\hline & & Inadequate & $162(28.1)$ & $121(25.3)$ & $41(41.8)$ & 2.12 & $(1.35 ; 3.33)$ & 0.001 \\
\hline & \multirow{2}{*}{$\begin{array}{l}\text { Gestational } \\
\text { age }\end{array}$} & Adequate & $442(76.7)$ & $369(77.2)$ & $73(74.5)$ & & & \\
\hline & & Inadequate & $134(23.3)$ & $109(22.8)$ & $25(25.5)$ & 1.15 & $(0.70 ; 1.91)$ & 0.564 \\
\hline & \multirow{2}{*}{$\begin{array}{l}\text { Blood } \\
\text { pressure }\end{array}$} & Adequate & $516(89.6)$ & $434(90.8)$ & $82(83.7)$ & & & \\
\hline & & Inadequate & $60(10.4)$ & $44(9.2)$ & $16(16.3)$ & 1.92 & $(1.03 ; 3.57)$ & 0.038 \\
\hline & \multirow{2}{*}{ Weight } & Adequate & $501(87.0)$ & $422(88.3)$ & 79 (80.6) & & & \\
\hline & & Inadequate & $75(13.0)$ & $56(11.7)$ & $19(19.4)$ & 1.81 & $(1.02 ; 3.21)$ & 0.042 \\
\hline & \multirow{2}{*}{ FHR } & Adequate & $505(87.7)$ & $419(87.7)$ & $86(87.8)$ & & & \\
\hline & & Inadequate & $71(12.3)$ & $59(13.3)$ & $12(12.2)$ & 0.99 & $(0.51 ; 1.92)$ & 0.979 \\
\hline & \multirow{2}{*}{$\begin{array}{c}\text { Fetal } \\
\text { presentation }\end{array}$} & Adequate & $77(13.4)$ & $67(14.0)$ & $10(10.2)$ & & & \\
\hline & & Inadequate & 499 (86.6) & $411(86.0)$ & 88 (89.8) & 1.43 & $(0.71 ; 2.89)$ & 0.315 \\
\hline
\end{tabular}

*Inadequate Quality: Sum of intermediate and inadequate.**Early initiation of prenatal care and number of visits (Kessner index).***First criterion plus minimum number of laboratory tests (proposed by Silveira, Santos and Costa, 2001) ${ }^{(15)}$. $^{* * * *}$ Second criterion plus obstetric minimum clinical procedures (proposed by Silveira, Santos and Costa, 2001) ${ }^{(15)}$. 
The association of prematurity with GA of early prenatal care $(\mathrm{p}=0.007)$ and number of visits $(\mathrm{p}=0.017)$ (first criterion) has been verified. When postpartum held insufficient number of visits and initiated prenatal after the $16^{\text {th }}$ week of pregnancy, the chance of premature births was nearly two times higher compared to those who initiated prenatal care early and made adequate number of visits $(\mathrm{OR}=1.99$, $\mathrm{CI}=1.20,3.28) ;(\mathrm{OR} 1.94, \mathrm{CI}=1.12 ; 3.34)$, respectively (Table 2). A similar situation was observed in association with the premature birth and indicators of the third criterion, which inadequate implementation of the clinical test of the uterine height $(\mathrm{p}=0.001)(\mathrm{OR}=2.12, \mathrm{CI}=1.35 ; 3.33)$, blood pressure $(\mathrm{p}=0.038)(\mathrm{OR}=1.92 ; \mathrm{CI}=1.03 ; 3.57)$ and weight $(\mathrm{p}=0.042)$ $(\mathrm{OR}=1.81, \mathrm{CI}=1.02 ; 3.21)$ is associated with premature birth.

Among the selected variables for multiple regression analysis to verify the association of the quality of prena- tal care for the first criterion and maternal characteristics (those with $\mathrm{p}<0.20$ in the univariate analysis) (Table 3), it is observed that socio-economic and individual characteristics (mixed funding of prenatal care $(\mathrm{OR}=3.98, \mathrm{CI}=2.13 ; 7.39)$, not planned pregnancy $(\mathrm{OR}=1.90, \mathrm{CI}=1.25 ; 2.87)$, no partner $(\mathrm{OR}=1.96, \mathrm{CI}=1.19 ; 3.21)$ and per capita income below 0.5 minimum wage $(\mathrm{OR}=1.75, \mathrm{CI}=1.01,3.03)$ and the characteristics of the reproductive history and pre-existing conditions (multiparity $(\mathrm{OR}=1.81, \mathrm{CI}=1.00,3.26)$ and interval between 60 months and over $(\mathrm{OR}=0.55, \mathrm{CI}=0.33 ; 0.90)$ are associated with inadequate prenatal care. It is noteworthy that the quality of prenatal care and the variables ethnicity/non-white skin, birth interval less than 24 months, anemia and hypertension were not associated in the univariate analysis $(p>0.05)$, however, they were analyzed by multiple regression $\mathrm{p}<0.20$.

Table 3 - Maternal characteristics and association with the quality of prenatal care - Maringa, PR, Brazil, 2014.

\begin{tabular}{|c|c|c|c|c|c|c|}
\hline \multirow{2}{*}{ Maternal characteristics } & \multicolumn{3}{|c|}{ Quality of prenatal care } & \multicolumn{3}{|c|}{ Univariate analisys } \\
\hline & Total $n=576(100 \%)$ & Adequate $n=424(73,6 \%)$ & Inadequate $n=152(26, \%)$ & OR & $95 \% \mathrm{Cl}$ & P value \\
\hline \multicolumn{7}{|c|}{ Individual and socioeconomic characteristics } \\
\hline \multicolumn{7}{|l|}{ Prenatal funding } \\
\hline Only SUS & $531(92,2)$ & $404(95,3)$ & $12783,6)$ & & & \\
\hline Mixed & $45(7,8)$ & $20(4,7)$ & $25(16,4)$ & 3,97 & $(2,13 ; 7,39)$ & $<0,001$ \\
\hline \multicolumn{7}{|l|}{ Planned Pregnancy } \\
\hline Yes & $207(35,9)$ & $168(39,6)$ & $39(25,7)$ & & & \\
\hline No & $369(64,1)$ & $256(60,4)$ & $113(74,3)$ & 1,9 & $(1,25 ; 2,87)$ & 0,002 \\
\hline \multicolumn{7}{|l|}{ Marital situation } \\
\hline With partner & $496(86,1)$ & $375(88,4)$ & $121(79,6)$ & & & \\
\hline Without partner & $80(13,9)$ & $49(11,6)$ & $31(20,4)$ & 1,96 & $(1,19 ; 3,21)$ & 0,008 \\
\hline \multicolumn{7}{|l|}{ *Per capita income (MW) } \\
\hline$<0,5$ & $78(13,5)$ & $51(12,0)$ & $27(17,8)$ & 1,75 & $(1,01 ; 3,03)$ & 0,044 \\
\hline 0,5 a 1 & $235(40,8)$ & $171(40,3)$ & $64(42,1)$ & 1,23 & $(0,82 ; 1,85)$ & 0,3 \\
\hline$>1$ & $263(45,7)$ & $202(47,6)$ & $61(40,1)$ & & & \\
\hline \multicolumn{7}{|l|}{ Ethnicity/color } \\
\hline White & $245(42,5)$ & $190(44,8)$ & $55(36,2)$ & & & \\
\hline Not White & $331(57,5)$ & $234(55,2)$ & $97(63,8)$ & 1,43 & $(0,97 ; 2,09)$ & 0,066 \\
\hline \multicolumn{7}{|l|}{ Work outside } \\
\hline Yes & $276(47,9)$ & $196(46,2)$ & $80(52,6)$ & 0,77 & $(0,53 ; 1,12)$ & 0,176 \\
\hline No & $300(52,1)$ & $228(53,8)$ & $72(47,4)$ & & & \\
\hline \multicolumn{7}{|c|}{ Reproduction history and pre-existing condition } \\
\hline \multicolumn{7}{|l|}{ Partum } \\
\hline Primiparity & $241(41,8)$ & $184(43,3)$ & $57(37,5)$ & & & \\
\hline Multiparity & $335(58,2)$ & $240(56,6)$ & $95(62,5)$ & 1,81 & $(1,00 ; 3,26)$ & 0,049 \\
\hline \multicolumn{7}{|l|}{ Birth interval (months) } \\
\hline$<24$ & $307(53,3)$ & $222(52,4)$ & $85(55,9)$ & 1,35 & $(0,86 ; 2,13)$ & 0,188 \\
\hline 24 to 59 & $120(20,8)$ & $79(18,6)$ & $41(27,0)$ & & & \\
\hline$\geq 60$ & $149(25,9)$ & $123(29,0)$ & $26(17,1)$ & 0,55 & $(0,33 ; 0,90)$ & 0,018 \\
\hline \multicolumn{7}{|c|}{ Characteristics and pregnancy complications } \\
\hline \multicolumn{7}{|l|}{ Anemia } \\
\hline Yes & $154(26,7)$ & $120(28,3)$ & $34(22,4)$ & 0,73 & $(0,47 ; 1,12)$ & 0,157 \\
\hline No & $422(73,3)$ & $304(71,7)$ & $118(77,6)$ & & & \\
\hline \multicolumn{7}{|l|}{ Hipertension } \\
\hline Yes & $113(19,6)$ & $89(21,0)$ & $24(15,8)$ & 0,7 & $(0,43 ; 1,15)$ & 0,167 \\
\hline No & $463(80,4)$ & $335(79,0)$ & $128(84,2)$ & & & \\
\hline
\end{tabular}

*Minimum wage during the time of the research in $2014(\mathrm{R} \$ 723.00)$. 
In the final model of association (Table 4), it is observed that inadequate prenatal care is associated with prenatal with mixed funding $(\mathrm{AOR}=5.70, \mathrm{CI}=2.93,11.09)$, ethnicity/color not white $(\mathrm{AOR}=1.67, \mathrm{CI}=1.11 ; 2.51)$, no planning of pregnancy $(\mathrm{AOR}=2.06 ; \mathrm{CI}=1.34 ; 3.17)$, and multiparity (AOR 2.18 CI=1.17; 4.03), regardless of other factors.

Table 4 - Final model of factors associated with quality of prenatal care - Maringa, PR, Brazil, 2014.

\begin{tabular}{lccccc}
\hline & \multicolumn{2}{c}{$\begin{array}{c}\text { Quality of prenatal } \\
\text { care }\end{array}$} & \multicolumn{2}{c}{ Logistic regression } \\
\cline { 2 - 6 } $\begin{array}{l}\text { Maternal } \\
\text { characteristics }\end{array}$ & $\begin{array}{c}\text { Adeq } \\
\mathbf{4 2 4} \\
\mathbf{( 7 3 . 6 \% )}\end{array}$ & $\begin{array}{c}\text { Inadeq } \\
\mathbf{1 5 2} \\
\mathbf{( 2 6 . 4 \% )}\end{array}$ & ORaj & $\mathbf{9 5 \%} \mathbf{C l}$ & $\begin{array}{c}\text { P } \\
\text { value }\end{array}$ \\
\hline Prenatal funding & & & & & \\
Only SUS & $404(95.3)$ & $127(83.6)$ & & & \\
Mixed & $20(4.7)$ & $25(16.4)$ & 5.70 & $11.09)$ & $<0.001$ \\
\hline Ethnicity/color & & & & & \\
White & $190(44.8)$ & $55(36.2)$ & & & \\
Not white & $234(55.2)$ & $97(63.8)$ & 1.67 & $(1.11 ;$ & 0.012 \\
\hline Planned pregnancy & & & & & \\
Yes & $168(39.6)$ & $39(25.7)$ & & & \\
No & $256(60.4)$ & $113(74.3)$ & 2.06 & $(1.34 ;$ & $0.17)$ \\
\hline Birth & & & & & 0.001 \\
\hline Primiparity & $184(43.3)$ & $57(37.5)$ & & & \\
Multiparity & $240(56.6)$ & $95(62.5)$ & 2.18 & $(1.17 ;$ & 0.013 \\
\hline
\end{tabular}

\section{DISCUSSION}

Prenatal care in the public health system of Maringa does not meet the completeness criteria recommended by the Brazilian Ministry of Health, especially when observing the quality of care results from the second and third criteria used for this evaluation. Although the first criterion present a more favorable outcome $(73.6 \%$ adequate for the entire sample), it is noticeable that $26.4 \%$ of mothers failed to receive the minimum recommended care, no satisfactory result, considering the importance of prenatal care for the mother and her child.

However, the proportion of adequate prenatal considering the first criterion (GA at the first visit and number of visits in accordance with gestational age) in Maringa, it was high when compared to the evaluation performed in Goiania-GO $\mathrm{GO}^{(19)}$, where prenatal care was only observed when GA initiated in the beginning of follow-up and the number of visits (35\%). In a study conducted in Rio de Janeiro- $\mathrm{RJ}^{(3)}$, it was observed that $74.4 \%$ of pregnant women began prenatal care before 16 weeks of gestation and 79.2\% had adequate number of doctors visits, slightly below the result found in Maringa (81.2 and 85.4\%, respectively).

The greater the number of indicators used, the greater the percentage of inadequate prenatal care, reaching $90.8 \%$ for the third criterion. Other studies have also observed a decrease and even absence of adequate prenatal care as it adds laboratory and clinical tests ${ }^{(2,19-21)}$, indicating that the recent public programs, national or state, Stork Network ${ }^{(22)}$ and Paranaense Mother ${ }^{(23)}$, advocating increased vigilance during pregnancy, have not yet reached their goals, drawing attention to the need for implementation of the preestablished protocols and strict observation of needs and characteristics specific of the assisted population.

In this study, the quality of prenatal care is associated with premature birth. For the three criteria used in the analysis were observed higher proportion of inadequate and intermediate prenatal care for mothers with premature babies, with 3.8 times more likely to adequate care when using the first criterion. This result once again shows that the quality of prenatal care, especially with regard to the early identification of pregnant women and the adequate number of doctor visits, thus, it is essential to ensure the completion of all procedures and conduct time during pregnancy ${ }^{(20-21)}$, playing an important role in preventing premature birth ${ }^{(4)}$.

It is worth noting, however, that even with late onset and reduced number of visits, it is possible to perform the minimum tests and procedures established by the Brazilian Ministry of Health ${ }^{(4)}$, especially in borderline prematurity situation (35-37 weeks gestation) - fact occurred to $74.5 \%$ of the 98 mothers who have had premature babies in this study (data not shown). The association of prematurity with each prenatal quality indicator individually showed that, except for hemoglobin and syphilis tests and verification of the FHR, all other indicators showed higher proportion of inadequacy for mothers with premature children. The high proportions of inadequate hemoglobin, syphilis, urine tests and clinical verification of fetal presentation for both mothers' groups seem to be key points or gaps responsible for the high proportion of inadequate prenatal care observed in the second and third criteria.

For good prenatal care monitoring, the health team should use early identification mechanisms for the pregnant woman and compensate for inadequate capture (with 16 and more weeks of gestation) by adopting shorter intervals between visits, ensuring the performance of the minimal visits number, access to diagnostic and therapeutic methods for maternal pathologies and monitoring of the fetal development and growth ${ }^{(3)}$.

The inadequacy of laboratory tests are essential for the diagnosis and treatment of maternal disease, which has long been discussed. Since the creation of Primary Care Program to Prenatal and Puerperium, there were indications that the achievements of the tests would be strong and difficult to manage ${ }^{(21)}$. Adequate performace and recording of tests provide detection of complications and disorders that may have repercussions of varying degrees of severity for the mother and the baby, and clinical tests allow us to monitor fetal growth and well-being ${ }^{(3)}$, collaborating in the prevention of preterm delivery.

We emphasize the association of premature birth and quality indicators of prenatal care to the third criterion (uterine height, blood pressure and weight). These procedures discussed in the literature ${ }^{(3-4)}$ for their importance in 
monitoring the health of the mother and developing baby, are performed during the doctors visits, not requiring sophisticated technology or additional costs, indicating that the relevant discussion is not only about number but also the quality of doctors visits for diagnosis and treatment of gestational complications.

Given the importance of adequate prenatal care in the prevention of preterm birth, as important as assessing the quality and detection of gaps of care is to know the maternal characteristics associated with inadequate care to intervene in them.

From the indicators referring to association of the quality of prenatal care for the first criterion and maternal characteristics selected for multiple regression $(p<0.20)$, there was predominance of prenatal inappropriate associations with individual and socioeconomic unfavorable characteristics (unplanned pregnancy, without partner, per capita income less than half of minimum wage). These results corroborate other studies that have also found a higher proportion of inadequate prenatal care for women with unfavorable characteristics, such as ethnicity/black and brown skin color ${ }^{(24)}$, who did not plan their pregnancy and unmarried, which tend to start Prenatal care late and perform fewer visits ${ }^{(1,25-27)}$.

Also, there was association of inadequate prenatal care to mothers who have made combined prenatal care $(\mathrm{OR}=3.9$ in the univariate analysis and $\mathrm{AOR}=5.7$ in the multivariate analysis). Performing sporadic prenatal visits by private health insurance may indicate favorable socioeconomic conditions, however, it must also reflect on the difficulty of access or dissatisfaction with the public service. A study conducted in Sao Paulo pointed out as main reasons for conducting pre-natal visits in various services, the dissatisfaction with the quality of care, delay in scheduling appointments, lack of experienced personnel and distance from the health facility designated to be attended ${ }^{(28)}$.

The multiparity, factor associated with inadequate prenatal care in the univariate analysis $(\mathrm{OR}=1.81)$ and multivariate analysis $(\mathrm{AOR}=2.18)$, is described as a risk factor both for inadequate prenatal care, and for premature birth ${ }^{(20,26)}$. It is believed that the experiences of other pregnancies can reduce the demand for prenatal consultations ${ }^{(8)}$, requiring intensified attention, especially the family health team members, who can act in the active search for pregnant women in this group and implement guidance and referrals.

Being pregnant 60 months before the current pregnancy was a protective factor for inadequate prenatal care in the univariate analysis $(\mathrm{p}<0.05)$, however, after adjustments in the final model of logistic regression, this association was not confirmed. Birth interval considered short, less than two years, or long, more than 5 years, hinders the adhesion of pregnant women to health care services and are considered risk factors for maternal complications such as eclampsia, pre-eclampsia and premature birth ${ }^{(4)}$.

The presence of anemia or hypertension, factors not associated in the univariate analysis $(p>0.05)$, but analysed in the multiple regression analysis $(\mathrm{p}<0.20)$, also had decreased prevalence of inadequate prenatal care, and although not confirmed as independent factors, in some cases, referrals to specialized care simultaneous monitoring in the Basic Health Unit ${ }^{(4)}$. In Maringa, services guided by Paranaense Mother Program ${ }^{(23)}$ appear to comply with this guidance, improving the quality of prenatal care for women with these risk factors.

In the final model of association, between the quality of prenatal care and maternal characteristics, few explanatory factors were observed for inadequate prenatal care. However, the combination of these factors reinforce the perception of greater risk of inadequate prenatal care among women with unfavorable socioeconomic and individual characteristics, confirming the persistence of disadvantages in health care for the underprivileged population, and the need for greater attention of the nurse and other members of the healthcare team for non-white pregnant women (black and brown), who did not plan the pregnancy, which used combined prenatal care and for multiparous, which are more vulnerable to inadequate prenatal care, they are also exposed to undesirable pregnancy outcomes, such as preterm delivery.

In this context, it is important to remember the importance of prenatal care and prematurity in neonatal and child mortality. A study conducted in a city in southern Brazil, with retrospective data of neonatal mortality at 10-year period showed, among other factors, prematurity and insufficient number of prenatal visits as the main determining factors for death at this stage of life ${ }^{(29)}$. Another study using estimates and data from the global infant and child mortality, while pointing to premature birth as the leading cause of mortality in children under 5 years of age, also highlights the importance of other causes that could be prevented with adequate prenatal care, such as tetanus and $\operatorname{AIDS}^{(6)}$, reinforcing the need for prenatal care that includes equity and full access to pregnant women.

Socioeconomic disparities and quality and demand for health services among Brazilian regions show differences in the incidence of premature birth. Such differences underscore the need for regionalized and localized studies to determine factors and consequences that lead to real need for action and public policies for the promotion, prevention and care to reduce the frequency of preterm birth ${ }^{(5)}$ and consequently child morbimortality.

\section{CONCLUSION}

The quality of prenatal care in Maringa is addressing early adaptation on the initiation of care and appropriate number of visits to gestational age, but presents difficulties in performing laboratory tests and clinical obstetric procedures, with higher prevalence of inadequacy among premature.

Linked to this, the quality of care involved a set of factors that permeate the socioeconomic characteristics of women, highlighting the need for greater attention to nonwhite pregnant women who did not plan the pregnancy, which performed combined prenatal care and multiparous.

Minimizing vulnerabilities through the organization of the assistance network, use of norms and recommendations of the Brazilian Ministry of Health and current scientific evidence can contribute to the control of risk factors and maternal disadvantages that predict inadequate prenatal 
and consequently prematurity. Part of premature births could be prevented with prenatal quality care and rigorous observation of the criteria recommended by the Brazilian Ministry of Health and national and state programs.

One of the limitations is the use of prenatal card as a source of information to evaluate the quality of prenatal care. Even with guidance to completeness of the data required for safe delivery, there are still underreporting cards and inconsistencies. It is necessary that nurses and other professionals working in prenatal adequately fill in the pregnant woman's card because the inconsistencies limit the evaluation of care and contribute to undesirable outcomes.

Also, it is important to highlight the limitation of the association analysis between the quality of prenatal care and premature birth, for which control variables were not used which also involve the quality of prenatal care, although the result observed in this study corroborates with the evidence reported in the literature.

\section{RESUMO}

Objetivo: Avaliar a qualidade do cuidado pré-natal em puérperas com nascimentos prematuros e a termo e identificar os fatores maternos e da gestação associados ao pré-natal inadequado. Método: Estudo transversal com coleta de dados do cartão da gestante, prontuário hospitalar e entrevista com puérperas residentes no município de Maringá-PR. Foram coletados dados de 576 puérperas e seus filhos nascidos vivos atendidos no serviço público no período de outubro de 2013 a fevereiro de 2014, utilizando três critérios distintos de avaliação. A associação da qualidade do pré-natal com prematuridade foi realizada por análise univariada e ocorreu apenas com o critério de Kessner ( $\mathrm{IC}=1,79 ; 8,02)$. Resultados: Os indicadores que mais contribuíram para a inadequação do pré-natal foram exames de hemoglobina, urina e apresentação fetal. Após análise de regressão logística, as variáveis maternas e da gestação que se associaram ao pré-natal inadequado foram a realização de pré-natal misto $(\mathrm{IC}=2,93 ; 11,09)$, cor da pele não branca (IC=1,11;2,51); gestação não planejada (IC=1,34;3,17) e multiparidade ( $\mathrm{IC}=1,17 ; 4,03)$. Conclusão: $\mathrm{O}$ cuidado pré-natal deve seguir os protocolos mínimos preconizados, com maior atenção a mulheres negras e pardas, multíparas e com gestações não planejadas, para prevenir prematuridade e morbimortalidade materna e infantil.

\section{DESCRITORES}

Cuidado Pré-Natal; Nascimento Prematuro; Enfermagem Materno-Infantil; Estudos de Avaliação.

\section{RESUMEN}

Objetivo: Evaluar la calidad del cuidado prenatal a las mujeres en el puerperio que tuvieron hijos prematuros y a término e identificar los factores maternos de la gestación asociados con el prenatal inadecuado. Método: Estudio transversal con recogida de datos de la tarjeta de la gestante, ficha hospitalaria y entrevista con mujeres en el puerperio del municipio de Maringá, Estado de Paraná. Fueron recogidos datos de 576 mujeres en el puerperio y sus hijos nacidos vivos atendidos en el servicio público en el período de octubre de 2013 a febrero de 2014, utilizándose tres criterios distintos de evaluación. La asociación de la calidad del prenatal con la prematuridad fue llevada a cabo mediante análisis univariado y ocurrió solo con el criterio de Kessner $(\mathrm{IC}=1,79 ; 8,02)$. Resultados: Los indicadores que más contribuyeron para la inadecuación del prenatal fueron los exámenes de hemoglobina, orina y presentación fetal. Después del análisis de regresión logístico, las variables maternas y de la gestación que se asociaron con el prenatal inadecuado fueron la realización de prenatal mixto (IC=2,93;11,09), color de la piel no blanco ( $\mathrm{IC}=1,11 ; 2,51)$, gestación no planificada $(\mathrm{IC}=1,34 ; 3,17)$ y multiparidad ( $\mathrm{IC}=1,17 ; 4,03)$. Conclusión: El cuidado prenatal debe seguir los protocolos mínimos preconizados, con mayor atención a las mujeres negras y oscuras, multíparas y con gestaciones no planificadas, para prevenir prematuridad y morbimortalidad materna e infantil.

\section{DESCRIPTORES}

Atención Prenatal; Nacimiento Prematuro; Enfermería Maternoinfantil; Estudios de Evaluación.

\section{REFERENCES}

1. Asundep NN, Jolly PE, Carson A, Turpin CA, Zhang K, Tameru B. Antenatal care attendance, a surrogate for pregnancy outcome? The case of Kumasi, Ghana. Matern Child Health J. 2014;18(5):1085-94.

2. Adane AA, Ayele TA, Ararsa LG, Bitew BD, Zeleke BM. Adverse birth outcomes among deliveries at Gondar University Hospital, Northwest Ethiopia. BMC Pregnancy Childbirth. 2014;14(1):90.

3. Domingues RMS, Hartz ZMA, Dias MAB, Leal MC. Adequacy of prenatal care in the National Health System in the city of Rio de Janeiro. Cad Saúde Pública. 2012; 28(3):425-37.

4. Brasil. Ministério da Saúde; Secretaria de Atenção à Saúde, Departamento de Ações Programáticas Estratégicas. Área Técnica de Saúde da Mulher. Pré-natal e puerpério: atenção qualificada e humanizada: manual técnico. Brasília; 2006.

5. Beck S, Wojdyla D, Say L, Betran AP, Merialdi M, Requejo JH, et al. The worldwide incidence of preterm birth: a systematic review of maternal mortality and morbidity. Bull World Health Organ. 2010;88(1):31-8.

6. Liu L, Oza S, Hogan D, Perin J, Rudan I, Lawn JE, et al. Global, regional, and national causes of child mortality in 2000-13, with projections to inform post-2015 priorities: an updated systematic analysis. Lancet. 2015;385(9966):430-40.

7. Melo EC, Oliveira RR, Mathias TAF. Premature birth: a public health challenge [editorial]. Ciênc Cuid Saúde. 2013;12(3):415.

8. Melo EC, Mathias TAF. Spatial distribution and self-correlation of mother and child health indicators in the state of Parana, Brazil. Rev Latino Am Enfermagem. 2010;18(6):1177-86.

9. Brasil. Ministério da Saúde. DATASUS. Informações de Saúde. Estatísticas Vitais. Nascidos vivos [Internet]. Brasília; 2013 [citado 2014 jun. 14]. Disponível em: http://www2.datasus.gov.br/DATASUS/index.php?area=0205 
10. Chang H, Larson J, Blencowe H, Spong CY, Howson CP, Cairns-Smith S, et al. Preventing preterm births: analysis of trends and potential reductions with interventions in 39 countries with very high human development index. Lancet. 2013;381(9862):223-34.

11. Paraná. Instituto Paranaense de Desenvolvimento Econômico e Social. Caderno estatístico: Município de Maringá [Internet]. Curitiba; 2015 [citado 2015 mar. 23]. Disponível em: http://www.ipardes.gov.br/cadernos/MontaCadPdf1.php?Municipio=87000\&btOk=ok

12. Brasil. Ministério da Saúde; Secretaria de Atenção à Saúde, Departamento de Atenção Básica. Atenção Básica e Saúde da Família. Diretriz Conceitual [Internet]. Brasília; 2014. [citado 2014 ago. 12]. Disponível em: http://dab.saude.gov.br/atencaobasica.php\#saudedafamilia

13. Almeida MF, Alencar GP, França Junior I, Novaes HM, Siqueira AA, Schoeps D, et al. Validade das informações das declarações de nascidos vivos com base em estudo caso-controle. Cad Saúde Pública. 2006;22(3):643-52.

14. Kessner DM. Infant death: analysis of maternal risk and health care. Washington: Institute of Medicine, National Academy of Science; 1973.

15. Silveira DS, Santos IS, Costa JSD. Atenção pré-natal na rede básica: uma avaliação da estrutura e do processo. Cad Saúde Pública. $2001 ; 17(1): 131-39$.

16. Pereira APE, Leal MC, Gama SGN, Domingues RMSM, Schilithz AOC, Bastos MH. Determinação da idade gestacional com base em informações do estudo Nascer no Brasil. Cad Saúde Pública. 2014; 30 Supl1:S59-70.

17. Brasil. Ministério da Saúde. Coordenação Geral de Informações e Análise Epidemiológica. Consolidação do Sistema de Informações sobre Nascidos Vivos [Internet]. Brasília, 2011. [citado 2014 set 17]. Disponível em: http://tabnet.datasus.gov.br/cgi/sinasc/Consolida_ Sinasc_2011.pdf.

18. Ananth CV. Menstrual versus clinical estimate of gestational age dating in the United States: temporal trends and variability in indices of perinatal outcomes. Paediatr Perinat Epidemiol. 2007;21 Suppl 2:22-30.

19. Costa CSC, Vila VSC, Rodrigues FM, Martins CA, Pinho LMO. Características do atendimento pré-natal na rede básica de saúde. Rev Eletr Enf [Internet]. 2013 [citado 2014 set. 27];15(2):516-22. Disponível em: http://dx.doi.org/10.5216/ree.v15i2.15635

20. Knight E, Morris M, Heaman M. A descriptive study of women presenting to an obstetric triage unit with no prenatal care. J Obstet Gynaecol Can. 2014;36(3):216-22.

21. Serruya SJ, Lago TG, Cecatti JG. Avaliação preliminar do Programa de Humanização no Pré-Natal e Nascimento no Brasil. Rev Bras Ginecol Obstet [Internet]. 2004[citado 2014 jul. 07]; 26(7):517-25 Disponível em: http://www.scielo.br/pdf/rbgo/v26n7/v26n7a03.pdf.

22. Brasil. Ministério da Saúde. Portaria n. 1.459, de 24 de junho de 2011. Institui, no âmbito do Sistema Único de Saúde - SUS a Rede Cegonha [Internet]. Brasília; 2011 [citado 2014 ago. 09]. Disponível em: http://bvsms.saude.gov.br/bvs/saudelegis/gm/2011/prt1459_24_06_2011. html

23. Paraná. Governo do Estado; Secretaria da Saúde. O que é a Rede Mãe Paranaense [Internet]. Curitiba; 2012 [citado 2014 set. 27]. Disponível em: http://www.sesa.pr.gov.br/modules/conteudo/conteudo.php?conteudo=2892

24. Cox RG, Zhang L, Zotti ME, Graham J. Prenatal care utilization in Mississippi: racial disparities and implications for unfavorable birth outcomes. Matern Child Health J. 2011;15(7):931-42.

25. Beeckman K, Louckx F, Downe S, Putman K. The relationship between antenatal care and preterm birth: the importance of content of care. Eur J Pub Health. 2012;23(3):366-71.

26. Fonseca SC, Monteiro DSA, Pereira CMS, Scoralick AC, Jorge MG, Rozario S. Desigualdades no pré-natal em cidade do sudeste do Brasil. Ciênc Saúde Coletiva. 2014;19(7):1991-8.

27. Bloch JR, Dawley K, Suplee D. Application of the Kessner and Kotelchuck prenatal care adequacy indices in preterm birth population. Public Health Nurs. 2009;26(5):449-59.

28. Corrêa CRH, Bonadio IC, Tsunechiro MA. Normative prenatal evaluationat a philanthropic maternity hospital in São Paulo. Rev Esc Enferm USP [Internet]. 2011 [cited 2014 Sept 06];45(6):1293-300. Available from: http://www.scielo.br/pdf/reeusp/v45n6/en_v45

29. Ferrari RAP, Bertolozzi MR, Dalmas JC, Girotto E. Determining factors for neonatal mortality in a city in the southern region of Brazil. Rev Esc Enferm USP [Internet] 2013 [cited 2015 Apr 01];47(3):531-38. Available from: http://www.scielo.br/pdf/reeusp/v47n3/en_0080-6234reeusp-47-3-00531.pdf 